\title{
VIOLENCE IN ROMAN POLITICS
}

By A. N. SHERWIN-WHITE

To speak of Roman politics in the late Republic without touching on violence would hardly be possible. ${ }^{1}$ But my real theme is concerned with methods of interpreting Roman history. We have seen in the last hundred years some three general attitudes or schools of thought about the study of the later Republic. It all begins with Mommsen, of course. First there were those who, following Mommsen, tended to explain Roman history in terms of the nineteenth century. The conflict of Optimates and Populares tended to be assimilated to the forms of conflict in parliamentary countries; parties, programmes, even democrats and conservatives were brought in. Then came a swing away. The stress was laid more and more on the generals and their ambitions. The terminology of parliamentary democracy was discarded as unsuitable, and the history of the late Republic was seen as an inevitable procession of great Imperatores, each foreshadowing the next. Even the Scipios were involved, then Marius, Sulla and so forth. Much less stress was laid on the popular movement. Apart from the Gracchi the tribunes were treated as tools of the Imperators and nothing more. The politics of the generation before the Social War were explained in terms of the Ciceronian age. One might cite the great chapters of the Cambridge Ancient History, and Meyer's Caesars Monarchie as characteristic.

Meantime a third school was coming into being, that of Münzer and family history. The details of aristocratic organization were minutely studied-which family backed which-who married whom. Terms such as clientela and factio began to dominate discussion. Roman politics were explained in terms of complicated combinations of family interest and Roman history took on an eighteenth century air. What happened at sessions of the Comitia and Senate was regarded as subject to a law of family determinism. The groups arranged it all beforehand. Families mobilized their vast clientelae to pass this law or that Senatusconsultum, to elect this or that man consul. The two preceding schools had not been unaware of the importance of family arrangements in Roman politics. Their exponents all knew why Pompey married Julia, and some knew that Tiberius Gracchus had powerful friends. But never before had such preponderance been given to the mechanics of social organization in politics. The new school was also very strong in the matter of power. The object of these family arrangements was to secure power for the family members. The bigger the group the more power it gets. Roman politics were seen to have reached the merger stage in the Ciceronian age. Gigantic family combinations produced gigantic personal commands. One thinks of the 200 senators at the so-called Conference of Luca.

Now these two latter schools have contributed much to the explanation of Roman history, and in varying combinations-since they are far from exclusive-may be said to dominate the present scene. But they suffer from certain defects in method. In the one case each decade or phase is explained in terms of the next ; the interpretation is evolutionary to the point of anachronism. Events are not studied sufficiently in relation to their own setting, but are illuminated by the light of a later age. The Münzer school falls into the opposite vice. Roman politics are represented as static; methods are taken to be the same after the Social War and the unification of Italy as before it. The age of Pompey is explained by the mechanisms of the age of Marius, and vice versa. One cannot do without these methods. For the broad sweep of events nothing is more illuminating than the representation of the series of great Imperators. The lines of perspective lead the historical eye inevitably to Caesar and the Principate. Equally in examining a particular moment of history we must know all about the family and personal relationships of the persons of the drama. But, when searching for the contemporary significance of events, actions should be judged by their own evidence and in their own context, without parti pris, and without forcing the future to appear in the past, and equally without the assumption that the rules of the family game were always kept-that no one ever changed his opinions or his side.

1 This paper was read at the conference arranged by the Committee of the Joint Greek and Roman Societies at Oxford in August, I 955 . The sources are well documented in Greenidge and Clay, Sources for Roman History B.C. 133-70 (Oxford, I 926), and in
T. R. S. Broughton, Magistrates of the Roman Republic (New York, 1951). Here references have been added to the original text only at places crucial for the argument. 
Not every marriage is significant, and if the Romans made political marriages one should remember that they also enjoyed a very lax system of divorce.

I propose to analyse two historical situations-in order to show how differently things appear in their own light when the illumination of a later age is removed, and rather more attention given to the immediate past than to the remoter future. First is a discussion of the career of Marius, and after that the events of the first consulship of Pompeius and Crassus are investigated.

\section{THE CAREER OF MARIUS}

Marius is commonly represented as the prototype of the military despots of the late Republic. Backed by his legionaries he wrests repeated consulships and agrarian laws from the teeth of aristocratic opposition, and as leader of a violent popular movement he breaks the authority of the senatorial government. But was it really like that at the time? Or does his career make better sense when explained in terms of the previous two generations than by those of the post-Sullan age?

The second century B.c. had seen a series of distinguished novi homines, men born outside the circle of aristocratic consular families, who by personal ability had reached the headship of the State, the consulship and Censura, and had themselves founded a noble family, in the technical sense of nobilitas. M. Cato was the most famous of these. Among the more recent was the first Pompeius, consul in I 40 B.c. and censor in I32, and P. Rupilius, a remarkable man who began life as a publicanus and secured his advancement under the wing of Scipio Aemilianus. It was the custom of the great houses to adopt promising ' new men' in this fashion. Relatively few reached the consulship-there were but two consuls a year-but many became Praetor. So too Marius. He was the son of a wealthy magnate of Arpinum, as is shown by the stories of his lavish bribery. He began under the wing of the great family of the Caecilii Metelli, who helped him to a tribunate in I 9 , in which he made a little display of independence, to put up his price. Such displays were part of the stock-in-trade of new men long before the age of the Gracchi. He just managed to secure a praetorship in I I5, and performed moderately in his Spanish province. Six years later he went to the Numidian war on the staff of his protector, $Q$. Metellus. ${ }^{2}$ This was his first such legateship. So far his career had developed with a slowness equalled only by its lack of distinction. He was 47 years old and had done nothing of note. When he informed Metellus in the course of 108 that he intended to stand for the consulship that year, Metellus thought the man mad, not without reason, and made the famous if tactless reply: 'It will be time enough to think of standing when my son is candidate.' It was the fashion of the second century for novi homines to become consuls thus in conjunction with a member of their protecting family. So Laelius with L. Scipio, and Cato with Valerius Flaccus. But Marius was not prepared to wait, and abandoned his connection with the Metelli. He had other irons in the fire.

So far Marius had taken no part in the politics of the radical group at Rome which had begun to agitate about certain scandals, first in the affair of the Vestals and then in the supposed abuses of the Jugurthan war. Sallust, the detailed source for the troublesome tribunates of Memmius and Mamilius, in IIo-rog, and for the electoral campaign of Marius in 108, makes a significant distinction. The politics of Memmius and Mamilius were concerned with the plebes and only the plebes. The so-called equestrian classes held aloof from popular politics, and supported the Senate, after abandoning Gaius Gracchus in 122, down to 108. Then Marius brought them into politics on the popular side in his electoral campaign, by the promise of a speedy end to the war if he were made consul. Such is Sallust's account. He may oversimplify. Such men as Memmius were themselves men of equestrian standing. But the distinction between equestrian and plebeian interest remains the key to Roman politics from 108 to 100 , and in the main Marius supported and was supported by equestrian interests. ${ }^{3}$ Before 108 the plebeian radical

${ }^{2}$ On the circumstances of Marius' legateship see Vell. Pat. II, I I. Plut. Mar., 7. Diod. 35, 38 .

${ }^{3}$ Compare Sallust, $B \mathcal{F} 27,30,31^{-} 3,40.3^{-5}$, with
$64 ; 65,4 ; 73$. For the rift between equestrians and plebes after Gaius Gracchus, ibid. 42, 1 . 
wing had been noisy, but of limited effect. Then there is a coalition of what Sallust calls plebes and equites Romani, and much progress is made. When this coalition breaks up in Ioo the popular movement collapses. But meanwhile Marius exploited plebeian and equestrian dissatisfactions which he turned to his personal advantage. Thus he won a consulship, and by a freak of fortune a succession of consulships. But he at no time supported any radical programme of reform; when Saturninus produced such a programme in Ioo Marius parted company with him.

Before Saturninus there was no such programme. Memmius and Mamilius had revived the Gracchan tradition in a narrower field. Such leaders as Memmius, and the troublesome Cassius and Norbanus in 106-5, confined themselves to criticism and prosecutions. They set themselves up as watch-dogs over the consular-senatorial administration, ready to bark and bite whenever consuls misbehaved or lost a battle. The Jugurthan affair and the disasters in Gaul at the hands of the Cimbri provided plenty of material. The tribunes had a merry time setting up tribunals for the correction of consulars. They were very rough with $Q$. Servilius Caepio, the proconsul who precipitated the disaster of Arausio in I05. But there was nothing beyond this. There was no attempt to diminish the role of the Senate in the government of Rome, and no Gracchan programme of social reform, no corn law, no agrarian bills.

All this suited Marius very well. He was able to exploit the invidia nobilitatis, just as Cato had once exploited the invidia Scipionis. He made a great show as the blunt but able soldier, kept out of the chief command by the jealousy of the nobles. But there is much exaggeration in the modern view that Marius stood for the principle of the career open to talent, and in the implication that he breached the fortress of the nobilitas for the benefit of all and sundry. Sallust is taken too literally. He may well be right in saying that the nobiles reckoned the consulship polluted if held by anyone but themselves. But he also states as a fact that Marius was the first novus homo to hold the consulship 'post multas tempestates'.4 How long is a tempestas? Is it a generation, or a decade, or only a year ? Rupilius, the consul of $\mathrm{r}^{2} 2$, only twenty-four years before, was indisputably a 'new man '; and there is a strong case for putting the consuls of 124 and II6, C. Sextius Calvinus and C. Licinius Geta, in the same category. It is difficult to think that Marius believed greatly in consulships for other ' new men'. In the nine years of his dominance Flavius Fimbria was the only other novus to be elected consul. Cicero remarks in the Brutus that the predominance of Marius prevented another good 'new man', G. Billienus, from securing the office. ${ }^{5}$

So far Marius' career was in the tradition of M. Cato, who at the beginning of the century had shown similar skill in exploiting popular discontent to secure his own advancement. Having won his consulship by intrigue, and ousted Q. Metellus from the command in Africa, Marius set about earning it by coping with Jugurtha. Then came the Cimbric crisis on the European front. Marius was elected in his absence, contrary to the Lex Annalis, to a second consulship. This resembles the case of Scipio Aemilianus at the time of the Third Carthaginian war, when the people swept aside the Lex Annalis and the allocation of provinces to make Aemilianus consul and commander ante tempus, when he was not even a candidate. Plutarch says that this very parallel was quoted at the time. ${ }^{6}$ So too in 108 the people by plebiscite had altered the Sempronian allotment to send Marius to Africa. ${ }^{7}$ Now they set aside the Lex Annalis in 105 to send the best man against the Germans. This could all have happened in the pre-Gracchan period. The use of the second consulship was a favourite device to deal with military crises. One thinks of Marcius Philippus, Aemilianus Paulus, and again Aemilianus. The exceptional thing in Marius is the series of consulships from ${ }_{104}$ to 100 . For this there was no parallel since the war against Hannibal. But the motive was the same and the Epitomator of Livy, who is not noted for his popular bias, states as much : ' his consulship was continued for several years because of fear of the Cimbri.' The Epitomator also makes it clear that this was done

4 ibid., 73.

5 For the origins of Rupilius see Val. Max. vi, 9, 8. For Billienus, Cic. Brutus 175 . Mallius Maximus, consul in 105, was ignobilis but not novus, Cic. pro Plancio 12.

G Plut. Mar. 1 2, I. 'Sall. BY 7.3. 
ex senatusconsulto, i.e. the Senate ratified the setting aside of the Lex Annalis. It is known from Sallust that the original allocation of Gaul to Marius was ex s.c. ${ }^{8}$ Had the war not lasted so long Marius would not have had so many consulships. He owed them to the failure of the Cimbri to turn up and fight when expected. But why did not the Senate simply prorogue the second consulship of Marius for as long as the war lasted? There was good reason. The great disaster of Arausio had been caused by the failure of a proconsul and a consul to co-operate on the same battlefield. The proconsul Caepio had disobeyed the consul Mallius and caused a crushing defeat. If Marius was to be generalissimo, he must at least be consul, or he might be found under the orders of another consul commanding another army in the same area; for no one could tell where in the north the campaign would be fought. There was at this date no other way round this constitutional difficulty. So Marius had to be re-elected consul until the Cimbri and Teutones were finished off.

But what about the consulship of Ioo? Surely that was unnecessary? The fighting in IOI was all over before the elections. Here at least one might see the military man supported by the soldiery making his bid for power with the help of his sinister henchman, Saturninus. The sources tell a different tale. They say in remarkable agreement that Marius was given his sixth consulship as the reward of his merits with the approval of the hitherto suspicious nobilitas, who admitted that he had saved the State. Only Rutilius Rufus, friend of the affronted Metellus and therefore enemy of Marius, muttered in his memoirs, not of violence and soldiery at the hustings, but of the bribery of voters. ${ }^{9}$ The truth is that Marius was steadily drawing closer to the consular class in these years. This appears also on his reluctance to stand for his fourth consulship, a well-known story, and in the voluntary sharing of his triumph at the end of ror with his optimate colleague, Catulus. But there remained the persistent opposition of the Metelli. At this juncture Plutarch says straight out that Marius was particularly afraid of Quintus Metellus, who was keeping a close watch on his activities. ${ }^{10}$ That is why Marius had to turn to Saturninus and the radicals to secure allotments of land for the war heroes who had defeated Jugurtha and the Cimbri. Even so the land was to be found not in Italy but overseas, a conciliatory gesture to the landed proprietors.

The story of Saturninus and Marius is a tale of misalliance. Saturninus is the real innovator of these years. He was fostering a scheme that would secure a great extension of the effective power of tribunes, a scheme that would enable tribunes not merely to pass general legislative reforms, as formerly, but also to intervene extensively in ordinary administration, and to subject the upper magistracies to a detailed control of their activities in a way that smacks of government by psephisma. This concerns Saturninus rather than Marius, and cannot be discussed at length here. The essence of the plan appears in the famous oath which Saturninus attached to his agrarian legislation in 100 , and to the lengthy document known as the 'piracy law' of roo by which Saturninus seems to have sought to control Asiatic affairs in considerable detail. The object of the oath was to use the Senate as an instrument by binding all senators and magistrates to carry out plebiscites, instead of neglecting them if contrary to their own ideas. The oath was not necessary for Marius and his veterans, and had not appeared in the first Marian land bill, that of ro3. Marius nearly broke with Saturninus when he heard of this oath; as presiding consul he brought it up for discussion in the Senate, and proposed a means of avoiding its effect. Only a singularly skilful intrigue on the part of Saturninus kept Marius with him for some time longer. Saturninus cunningly used the oath to effect the downfall and exile of Marius' arch-enemy Metellus. ${ }^{11}$ The consummation of the vendetta may have comforted Marius. But during the year the equestrian element became more and more dissatisfied with the dodges of Saturninus, culminating in the astonishing murder of the senior and respected

\footnotetext{
${ }^{8}$ Livy, $E p .67$. Sall. $B \mathcal{Y}$ I 4.

9 Vell. Pat. II, 126. Livy, Ep. 68-9, gives both sides of the picture. Plut. Mar. 28, 5, gives the Rutilius version. Cf. Dio's statement on the 'consensus omnium' at the elections of 102, fr. 92 .

${ }_{10}$ Plut. Mar. 28, 4.
}

\footnotetext{
11 App. 1, 30, 3-6. Plut. Mar. 29, 2 and 4. The bias of the source is apparent. Marius could not have known beforehand that Metellus alone of all the senators would refuse to take the conditional oath. Saturninus' trick could only be devised after the final taking of oaths.
} 
radical leader, Memmius, at the consular elections. This was too much for Marius and his equestrian friends. The popular coalition dissolved into its component parts. Marius intervened as consul under the authority of the Senate, and with the help of a posse of Roman knights he eliminated the too enterprising leader of the plebs. ${ }^{12}$

Where in all this is the political general, the first of the military despots in disguise? At this stage of Roman history neither generals nor legionaries were ready to support one another with armed violence in the civil sphere. It is not as organized legionaries but as citizens that the discharged veterans make their contribution in the year 100. The point of Marius's actions is not that he calls upon his veterans to support his interests. He does no such thing. But he supports their interests. The Marian army reforms took a sinister turn only when a general appealed to his troops to help him against the Senate or the Comitia. That happens from 88 B.c. onwards, but not before the Social War. The story of Sulla's coup d'état shows that it never occurred to Marius and his associate, Sulpicius Rufus, that the consul Sulla might refuse to obey the plebiscite that legally deprived him of his eastern command. Metellus in I07 had obediently gone home when deprived of Africa, and they expected Sulla to do likewise in 88 . He did not, and thereby the violent phase of the late Republic began.

Marius in 88 , and still more in 100 , was conditioned by the political habits of the second century. However much in retrospect he may seem the prototype of the political Imperators of the later age, the analogy is misleading. These things lay as seeds in the womb of time. The Social War fertilized the Marian army reform and begot the Revolution. But that was not yet. Marius was an unimaginative child of his age. He wanted to be a second Cato, or a second Q. Pompeius. It is characteristic that in the period after roo he was ambitious to hold the censorship of 97 with his friend and former fellow consul, Valerius Flaccus. So too some ninety years before old Cato had been censor with his friend and former colleague, an earlier Valerius Flaccus. Marius feared a defeat at the censorial elections, and in the end he did not stand. ${ }^{13}$ But the ambition, and the disappointment which he is said to have felt, was characteristic. Marius wanted to end his days as vir censorius, like the other great worthies among the novi homines of the second century.

\section{POMPEIUS IN $7 \mathrm{I}-70$ B.C.}

English historians have a short way with the events of $7 \mathbf{I}-70$ B.C. Professor Syme in the Roman Revolution says : 'Pompeius combined with another army commander and carried out a peaceful coup d'état.' The Cambridge Ancient History takes the same line : 'the two marshals now advanced on Rome, where the Senate was even more defenceless than in 77 B.c.' The whole story of $7 \mathrm{I}-70$ is then represented as a dictate. ${ }^{14}$ Pompeius under threat of civil war takes an illegal consulship and overthrows the constitution of Sulla. I know of no voice that dissents from this view. It may be the truth but it is not the whole truth, and in its tones and overtones and in certain essential details it is a modern invention.

The sources for the politics of $7 \mathbf{I}-70$ are remarkably brief for such great events. A collection of sundry sentences in various writers bears on the legislation of 70 , but the continuous narrative of events appears only in the last page of Appian Bellum Civile I, and in a page-and-a-half of Plutarch's life of Pompey, repeated more briefly in his Crassus. ${ }^{15}$ Plutarch is the more detailed. He says that when Pompey, after finishing off the revolt of Spartacus, marched towards Rome, there was some fear and suspicion because men were afraid that he would not disband his army, but would wade through arms and despotic power against the settlement of Sulla. Hence as many came out to greet him through fear as through gratitude for his victories. But he dispelled this fear by declaring that he would disband his army after his triumph. After that pronouncement the only complaint against him was that he was too much on the popular side, in that he had decided to restore the

${ }_{12}$ Plut. Mar. 30, 3. Cic. pro Rab. perd. reo. 20, 27. Cf. Orosius v, 17.

is Plut. Mar. 3o, 4.
14 R. Syme, Roman Revolution, 29. H. M. Last in $C . A H \mathrm{Ix}, 332$.

15 App. $B C$ I, 121. Plut. Pomp. 21, 3-23, 2. Crass. 12. 


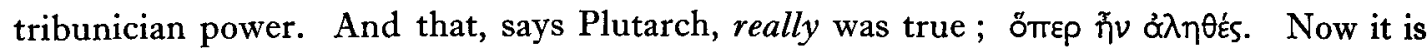
known from Velleius that Pompey celebrated his triumph on the last day of $7 \mathbf{r}{ }^{16}$ Plutarch indicates that Pompey kept his word, and the army was disbanded, and that of Crassus also, straight away. Besides, how could he retain his army after crossing the Pomerium ?

In Appian there is a slight difference, which is the basis of the modern version. Speaking of 7 I down to the consular elections he says that Crassus would not disband his army because Pompey did not do so, and that they continued to keep their armies in being after the elections, Pompey using the excuse that he was waiting to share his triumph with Metellus Pius. Appian then describes a scene which he seems to place during the consulship of the two men in 70 -and this is the only description of 70 that he gives. The People, fearing a civil war between the two, persuade them to accept a formal reconciliation, and after this to disband their two armies. Now this reconciliation is described with more detail by Plutarch, who does not connect it with the question of the armies, already dismissed, but relates it to a long series of quarrels between the two during their consulship, names the chief agent of the agreement, and dates it to the last day of 70 .

It is apparent that Appian has made one of his famous muddles. He has telescoped the triumphal celebrations and dismissal of armies at the end of $7 \mathrm{I}$ with the reconciliation scene at the end of 70 . Hence Plutarch is right, and there were no armies in being round Rome during the year 70 . But it is even more remarkable that neither historian makes the threat of armed force the immediate cause of the consulships and legislation of 70 . Plutarch dismisses the threat as unreal, and Appian regards the armies of the two men as aimed not at the State or the Senate, but at one another. Neither gives the modern version, the march on Rome and the dictate. This might be due to a later whitewashing of the tradition about Pompey. But several considerations suggest that the threat of force in $7 \mathrm{I}$ was remote. Who after all was Pompey, why did he want a consulship, exactly how illegal was this desire, and what use did he make of his consulship ?

The young Pompeius had certainly had a strange career, post on post, and all without regard for the Sullan Lex Annalis : the commission under Catulus against Lepidus followed by the imperium against Sertorius, ' non proconsule sed pro consulibus.' But this had been done as Cicero said of Sulla 'pro optimatibus '. For ten years Pompeius commissioned by Sulla or the Sullan Senate had been slaughtering the leaders and other ranks of the populares, in Sicily and Africa, in Cisalpine Gaul and in Spain. Thanks to him the Optimates and their henchmen slept snug in their beds, and Sullan possessores enjoyed their ill-gotten gains.

A strange candidate this for the leadership of an anti-Optimate coup at Rome. True, the man had had difficulties during his war with the clique that ran things in the postSullan decade. Supplies, with or without excuse, had been kept in arrears. It had ever been the way of the Roman oligarchy to prune the tallest poppies, and there may have been those, now as later, who wanted to take Pompey down a peg. But all that Pompey required in $7 \mathrm{I}$ for himself was the regularization of his position. In a famous scene he reported to the censors of $7^{\circ}$ that he had done all his military service se imperatore. This rubbed in the incongruity of his position the year before. Not for him now to toil through the lesser magistracies. One stride to the consulship, and he would be in the place due to his dignitas, as the son of a consular, ' tantis rebus gestis.' As with Catalina and Caesar later it boils down to the very Roman question of status dignitatis. Pompey wanted the consulship, not to secure a new command, but to be consularis. He and Crassus both refused provinces at the end of the year, and he did nothing else for himself in 70 at all. But men who want to be consular are by definition not men who want to start revolutions.

What, next, about the supposed illegality of his consulship under the Sullan rules? Pompey was not asking for the office itself, but for a dispensation from the Lex Annalis regulating candidatures which the Senate under the Sullan system was perfectly competent to grant. ${ }^{17}$ Such dispensations for individuals, sometimes loosely called privilegia, played a marked part in the senatorial intrigues of the post-Sullan decade-so much so that the

16 Vell. Pat. II, 30.

17 Pompey was granted dispensation to hold his triumph in 71 by the Senate, Cic. de Imp. Pomp. 62.
The sc. allowing ratio absentis would be at the same time. 
tribune Cornelius in 67 brought in a bill aimed at the abusive grant of such privileges. Sulla meant the Senate to govern the Roman State, and left it with the power to take extraordinary measures if they were necessary. The constitution did not crumble in 74 when Lucullus managed to change his consular province for the command against Mithridates, or when the worthless Antonius was given wide powers to deal with pirates. It was no worse to dispense a man in the odd position of Pompeius from the formal requirements of the Lex Annalis. It is the modern doctrine of precedent that makes the step seem revolutionary. One such concession, and the Lex Annalis is annulled. So we think, but that was not the Roman way of thinking, least of all of legal thinking. During the next two decades the Lex Annalis continued to mould the careers of men unchallenged, and notably that of Julius Caesar.

But, say the objectors, Pompey was no friend of the Senate. What about Lepidus in $79-78$, and the army at the gates in $7 \mathrm{I}$, and the laws of 70 ? The remarkable thing about the intrigue of Pompey with Lepidus is that the moment that Lepidus revealed a really revolutionary intention, Pompey turned away from him and supported the Optimates. It is a well-known fallacy by now to speak as though the Senate were a coherent political party. No Roman politician ever had the whole Senate, or even all the Optimates, on his side. Pompey had friends and enemies, in the Roman sense, like anyone else. His friends had secured him notable concessions in recent years, not only the commands of $78-77$ but such enactments as the consular law of 72 which confirmed his grants of citizenship to persons in Spain. And now his friends secured him two decrees allowing him to celebrate a triumph and to stand for the consulship, in return for his notable services to the Optimate cause. What less could they have done? One thinks of Marius and his sixth consulship, praemium meritorum.

But, they say, this was under the threat of armed force. No such thing. Pompey and Crassus did not march on Rome, they marched to Rome, as they were entitled to do, to hold well merited triumphs. They were elected in technical absence to consulships, disbanded their armies, and entered the city. So too in the year I 80 B.C. Livy records that the praetor, Q. Fulvius Flaccus, returned from Spain with an army and a great reputation, and while he was outside the city because of his triumph he was elected consul though absens, and a few days later entered the city with his troops in a formal procession of triumph. ${ }^{18}$ In 7 I the thought of civil war existed according to the only source that discusses the matter, not in the intentions of Pompey but in the minds of the Roman population, and was false. No doubt Pompey played a little on this fear and exploited the psychosis of the age. But it fits neither the character nor the circumstances of Pompey in 71 that he contemplated an armed seizure of Rome against the Optimates. One needs more than an army for such a move. Pompey with an army and the backing of the Optimates, or Caesar with an army and the backing of equestrian interests, may try to solve political problems by force. But for the aduluscentulus carnifex fresh from the butchery of Sertorius to start a civil war against the Optimates makes nonsense. Besides, what would Crassus and Metellus and their not inconsiderable armies do while Pompey was seizing Rome?

Next for Pompey's part in the legislation of 70 . Pompey promised his support for the restoration of the tribunate before the elections. It was his bid for votes. The Comitia Centuriata was largely under the influence of the Optimate families, as always, among whom Pompey had many enemies. He offset this by cashing in on a promising situation, as Plutarch remarks. The agitation for the restoration of the tribunate was at its height; Pompey added his support, and his election was secure. With the Optimate influence divided, and the popular vote estranged, it was necessary to make some electoral gesture. Pompey quickly redeemed his legislative pledge in 70 , but only after consulting the Senate in a debate at which the arch-Sullan Catulus conceded that this was a necessary change; and the bill was passed ex senatus consulto. Cicero reveals this in the First Verrine. ${ }^{19}$

The judiciary law, which altered the Sullan system of political juries, was a careful bill which gave the control to a body that was constituted very differently from the old Gracchan panel. There is evidence that Pompey was not greatly interested, though he

$$
18 \text { Livy } \mathrm{xL}, 43,4-5 . \quad 19 \text { Cic. I in Verr. } 44 .
$$


touched on the question in his contio as consul designate. Cicero in the Verrines insists that this bill was the child of L. Cotta, not 'one of us', he says, but a homo nobilissimus.

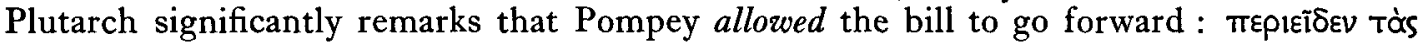

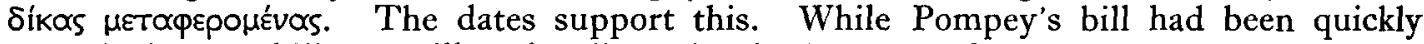
passed, the jury bill was still under discussion in August $70 .{ }^{20}$

Those who take the mailed fist view of these events usually concede that the mailed fist was duly gloved in velvet. But even they have difficulty in explaining why Pompey did nothing for his all important army. Some have suggested that something must have been done, though not recorded. But Cassius Dio in a little noticed passage reporting a speech of Pompey in 59 B.c. has a reference back to 70. ${ }^{21}$ Pompey says that formerly the Senate itself proposed a distribution of land to the veterans of Pompey and Metellus, but that the proposal was not carried out, 'quite reasonably,' because the Treasury was then short of cash. A queer warlord this, who so lightly lets a Senate which is supposed to be terrified of him, cheat his precious troops out of their due. In fact the incident reveals a very different, and much more political, situation at Rome in 70 . At every crucial moment we find Pompey working through, not in defiance of, the Senate, as he had done since the beginning of his career. It had served his purpose in the past, and might do so again.

True, Pompey freed the tribunate from the shackles of the Sullan legislation. To the modern view this means the downfall of the Sullan system and, what is taken for the same thing, the near collapse of the Republic. But men like the Aurelii Cottae, who first broached the matter, and Cornelius the tribune, who carried on the work of 70 in 67 , would say not that they were destroying the Republic, but that they were restoring it. Hence also the revival of the censorship at this time.

Pompey emerges, not the blunt man of action drawing a gun on the Senate, but as we meet him in Cicero's letters, the cunning prevaricator, Mr. Facing-both-ways, who makes haste slowly, who is ever ready to cash in on a promising situation, but never goes too far. This is the Pompey of the debates on the restoration of Ptolemy Auletes, the Pompey who allowed the recall of Cicero. Not Magnus but Catus. He would bluff up to the limits of legality, but he never marched on Rome or crossed a Rubicon in his life. He disbanded his legions at Brundisium on his return from the East. In his own phrase he would take a sword, but only if the consuls placed it in his hands; if someone else drew a sword he would raise a shield.

As for the damage to the Sullan system, it was less extensive than is commonly assumed. A great part of Sulla's aim had been to give the Senate effective power over the administration. The Lex Annalis and the penal laws, the treason law and the extortion law, were the main instruments. These remained in full force despite the concession to Pompey, and the penal laws were meant to be enforced more, not less, vigorously by the new jury panel. The weakness of the post-Sullan Senate lay not in the fact that it took extraordinary measures to deal with extraordinary situations - that was its job-but that it failed to enforce the public laws in its own court impartially upon big men and little men alike. This failure was apparent before 70 , as Catulus publicly admitted and Cicero fully documented in the Verrines and the pro Cluentio. Metelli and Luculli go unchecked in their extortions and malpractices, while a Fidiculanius or Septimius falls into trouble. The legislation of 70 came too late. The greatest names remained immune from the controls whereby before the Social War the proconsuls had been kept in some subservience to the State. The Senate's failure as a corporate body lies not in its weak reaction to external pressures, but in its acquiescence in the corruptions of the Optimate cliques within. It was because they would not discipline themselves that they were in no position to discipline Pompey. The condemnation of some great Optimate in the seventies would have gone far to instill caution into those who murmured : 'Sulla potuit, ego non potero ?'

20 For the author and date of the Aurelian rogation see o.c. 46, 11; in Verr. 11, 174; 111, 223. Plut. Pomp. 22, 3. For Pompey's contio see I in Verr. 45.

21 Dio $38,5,1-2$. Professor R. E. Smith in a forthcoming article, which he kindly communicated to me, links this with the obscure lex Plotia that formed the model for the agrarian rogation of Flavius in 60 B.C. Cic. ad Att. $1,18,6$. 


\section{CONCLUSION}

So much for Marius and Pompey. If these two analyses have established anything apart from a salutary reminder not to forget the sources in the spinning of theories, it is that each decade or age should be interpreted by its own light rather than by that of a succeeding age, and that by this difference of emphasis, such as it is, a new look can be given to the series of episodes that make up the history of the later Republic. The value of this new look is that, if the job is properly done, one comes closer to the texture of the ancient world; one tries to see events not in retrospect, not even through the eyes of Sallust or Tacitus, as is so fashionable nowadays, but through the eyes of the actors themselves. This is seldom very easy, given the nature of our sources. But however erroneous some of the preceding arguments may be in detail, something of importance emerges. This is not the whitewashing of an age in which violence could not be always avoided, but the underlying legality of the Roman outlook. There has for long been a sad divorce between the study of Roman politics and of Roman law. It sometimes seems impossible to believe that the despotic figures who appear in modern studies could belong to the folk who producedwho were already producing - the Roman civil law.

Professor A. H. M. Jones has salutarily remarked in his recent article on the Principate of Augustus ${ }^{22}$ that there was a numerous element in the municipalities of Italy who were disgusted by the methods of the Triumviral period, and insisted if not on law at least on legality. He might have gone further. The leaders themselves seem to have little taste for their own revolutions. They lack the gusto of a Central American politician for the method of violence. These things were sometimes forced upon them by the logic of events, but they did not enjoy them. This makes sense of Roman history as a whole. A genius for civil law, for civil administration, for municipal government, for compromise in the handling of provincial subjects, all these qualities fit very oddly with an unabashed preference for power politics. Sulla and Octavian were the exceptions. Marius and Pompey, like many another, instinctively took the path of law and custom.

$22 \not{F R S} \mathrm{XLI}, 195 \mathrm{I}, 112$. 